\title{
Um Modelo para o Compartilhamento de Conhecimento no Trabalho
}

\author{
Helena Correa Tonet \\ Maria das Graças Torres da Paz
}

\section{Resumo}

O artigo focaliza o compartilhamento de conhecimento no trabalho, que é de suma importância para as organizações, mas de difícil concretização; pretende suprir uma lacuna percebida na literatura, que trata o tema de forma ampla, considerando o processo de transferência de conhecimento na organização; no modelo aqui proposto, o foco principal é o compartilhamento que ocorre nos grupos de trabalho, sendo a organização considerada como elemento do contexto em que esses grupos estão inseridos. Descreve o compartilhamento de conhecimento como processo integrado por 4 fases, iniciação, implementação, apoio e incorporação. Relaciona a cada fase situações pessoais e organizacionais que poderão ocorrer e interferir no compartilhamento, e oferece orientações para ajudar a refletir sobre os elementos fonte, destinatário, o conhecimento em si, e o contexto, que integram o processo de compartilhamento de conhecimento entre pessoas. A proposta do modelo está ancorada na Teoria de Sistemas (Bertalanffy, 1975) e em teorias da comunicação humana (Berlo, 1970; Thayer, 1979; Thompson, 1973).

Palavras-chave: compartilhamento de conhecimento; conhecimento no trabalho; modelo de compartilhamento; conhecimento.

\begin{abstract}
This article focuses on the sharing of knowledge at work, which is very important for organizations, but very difficult to achieve. It intends to fill in a gap left in literature, that concerns this theme vastly when we consider the transference of knowledge process in organization. The main point in the model proposed here is the sharing that occurs in work groups, the organizations being considered as the he context element in which these groups are inserted in. It describes the sharing of knowledge as a process composed by 4 phases, iniciation, implementation, support and incorporation, and it relates each phase to personal and organizational situations which might occur and interfere with the sharing. It also gives orientation to help on the reflection about some elements such as the source, the receiver, the knowledge itself and the context - the elements which integrate the sharing of knowledge process among people. The model proposed is based on the Systems Theory (Bertalanffy, 1975) and on the Human Comunication Theories (Berlo, 1970; Thayer, 1979; Thompson, 1973).
\end{abstract}

Key words: sharing of knowledge; knowledge at work; model for sharing; knowledge. 


\section{INTRODUÇÃO}

O avanço tecnológico tem colocado evidências muito claras do que é possível fazer com a posse de conhecimento, que cada vez mais é agregado a produtos e serviços. A aplicação de conhecimento na produção agrícola, por exemplo, mudou a feição dos nossos campos produtivos; a latinha que hoje envolve qualquer tipo de refrigerante ou suco é $80 \%$ mais fina que os primeiros exemplares usados no segmento industrial; um palm top possui hoje mais capacidade de memória do que os primeiros computadores, que à época assombraram o mundo dos serviços.

No ambiente das organizações e dos negócios, o interesse pelo conhecimento acentua-se a partir da constatação, por exemplo, de que o valor de mercado de algumas empresas chega a ser inúmeras vezes maior do que o valor do patrimônio financeiro e físico que possuem; suas ações valem tanto, porque incorporam valores intangíveis, como a marca e a imagem que possuem em face dos mercados, a capacidade de inovação, o talento dos seus executivos, a competência dos empregados. Grande parte desse valor intangível é agregada pela posse de conhecimento, que resulta da incorporação de novas experiências, de reflexão, da aprendizagem contínua e compartilhada.

Para as empresas, o compartilhamento de conhecimento no trabalho é uma forma de assegurar que seus colaboradores ou empregados possam estar repassando uns aos outros o conhecimento que possuem, e garantindo a disseminação e posse do conhecimento de que necessitam. Grande diferencial de competitividade de uma organização é a sua capacidade de otimizar a reutilização do conhecimento, que muitas vezes fica restrito a indivíduos ou a algumas áreas, enquanto os demais lutam com problemas que poderão ser solucionados com o conhecimento já dominado internamente. Para os empregados e trabalhadores, de uma forma geral, compartilhar conhecimento é um procedimento para ajudar a suprir a necessidade de aprender continuamente, imposta a cada profissional que deseja manter-se qualificado para o trabalho que realiza.

No atual cenário das organizações, o compartilhamento de conhecimento tem mostrado ser de suma importância, mas de difícil concretização; embora o senso comum identifique facilmente o que é compartilhar conhecimento, ainda não há consenso empírico sobre o significado do construto. Neste artigo, compartilhamento de conhecimento é definido como o comportamento do indivíduo de repassar o que sabe a pessoas com quem trabalha e de receber o conhecimento que elas 
possuem. A consequiência esperada desse comportamento é que o destinatário ou receptor assimile o conhecimento compartilhado pela fonte ou emissor.

$\mathrm{O}$ artigo propõe um modelo para orientar o compartilhamento de conhecimento no trabalho, que é tratado como processo integrado por quatro fases. Discute também os principais elementos que integram esse processo, apontando suas principais características, e apresentando medidas para viabilizar um estado organizacional propício ao compartilhamento de conhecimento.

\section{Aspectos e Situações que Podem Interferir no Compartilhamento de Conhecimento}

Ainda não existe consenso sobre o que é e como ocorre o compartilhamento de conhecimento entre as pessoas. A literatura, às vezes, registra outras denominações para esse processo, como transferência, repasse, ou disseminação de conhecimento. Há também certa sobreposição entre as expressões compartilhamento de conhecimento e compartilhamento de informação, embora vários autores já tenham clareza a esse respeito, distinguindo e hierarquizando os termos: dado, informação e conhecimento.

Bartol e Srivastava (2002) definem compartilhamento de conhecimento como sendo o compartilhamento de informações, idéias, sugestões e experiências organizacionalmente relevantes, do indivíduo com outros, e afirmam que o compartilhamento de conhecimento é um componente chave dos sistemas de gestão do conhecimento. Szulanski (2000) fala em transferência do conhecimento, ressaltando que essa transferência não deve ser vista como um ato em que uma pessoa passa algo a outra, e sim, como processo, constituído de diferentes estágios, cada um com suas dificuldades próprias.

O compartilhamento de conhecimento nas organizações sofre a influência de inúmeras variáveis, que podem impactar esse processo de diferentes formas (Davenport \& Prusak, 1998; Nonaka \& Takeuchi, 1997; Szulanski, 2000). Entre elas, estão variáveis relacionadas com o conhecimento transferido, com o transmissor e o receptor do conhecimento, e com o contexto em que ocorre o compartilhamento do conhecimento. No tocante a variáveis que configuram barreiras ao compartilhamento advindas da própria organização, incluem-se as relacionadas à estrutura, aos processos operacionais, à cultura e ao clima organizacional (Terra, 2000).

Para ocorrer o compartilhado de conhecimento há necessidade de existir uma 
linguagem comum entre as pessoas que atuam na organização. Grande obstáculo está exatamente nesse aspecto: muitas vezes o conhecimento a ser compartilhado envolve vocabulário inovador para os receptores, ou envolve termos que acabam sendo decodificados de forma diferente daquela pretendida pelo emissor. Sveiby (1998, p. 49) afirma que "o significado que uma pessoa expressa nunca é o mesmo que aquele gerado na mente da pessoa que o recebe". Pode também ocorrer que o próprio emissor tenha dificuldades em traduzir em palavras o conhecimento que deseja compartilhar com os demais, e até mesmo que não tenha palavras adequadas para isso.

Segundo Szulanski (2000) o compartilhamento do conhecimento depende da capacidade de absorção do destinatário, que está relacionada com o conhecimento e habilidades anteriores e com a motivação que possui para buscar e aceitar conhecimentos diferentes ou novos. A falta de motivação nesse sentido poderá levar a atitudes de procrastinação, rejeição, sabotagem, passividade, aceitação na implementação e no uso do conhecimento compartilhado.

Goman (2002) conduziu survey junto a 200 gerentes de nível médio, buscando conhecer as razões mais freqüentes que dificultam ou impedem o compartilhamento de conhecimento, concluindo que as pessoas não compartilham conhecimento porque entendem que, assim fazendo, terão algum poder sobre os demais que não possuem o mesmo conhecimento. Maturana e Varela (2001) afirmam que as pessoas recebem os estímulos do ambiente, de acordo com as experiências que possuem e as crenças que postulam sobre o mundo. Krogh, Ichijo e Nonaka (2001) citam a existência de pelo menos 2 barreiras individuais: baixa capacidade de acomodação e ameaça à auto-imagem. Dizem também que ao compartilhar conhecimento no trabalho, os indivíduos precisam justificar em público as suas crenças, e para isso enfrentam quatro grandes barreiras organizacionais: (1) necessidade de linguagem legítima, que permita explicitar o conhecimento tácito; (2) histórias organizacionais; (3) procedimentos predefinidos; (4) os paradigmas da empresa.

Além dessas, outras barreiras podem ser lembradas, como a falta de compreensão dos processos internos da organização. A compreensão desses processos permite às pessoas regularem o próprio comportamento, orientandose, por exemplo, na interpretação do que ocorre na organização, e no estabelecimento de vínculos com as outras pessoas. A aceitação de um conhecimento que esteja sendo compartilhado poderá ser comprometida por histórias e crenças que permeiam a cultura organizacional. Frases como "já vimos esse filme antes"; "isso já foi tentado e não deu certo"; "aqui a voz do dono soa mais alto" são exemplos que denotam barreiras ao conhecimento diferente ou novo e ao seu compartilhamento, advindas da cultura interna. 
Em grande parte das organizações, os procedimentos vigentes não permitem flexibilização das rotinas, ou adaptações a demandas específicas; muitas vezes, tais procedimentos visam exatamente a manter sem alterações a forma de execução das atividades, e preservar as situações operacionais existentes. Dificilmente as pessoas são encorajadas a reexaminar as suas rotinas de trabalho e a combater os procedimentos operacionais ineficazes. Os manuais de procedimentos, quando imutáveis, mais do que orientar a execução, funcionam como amarras que impedem as pessoas de encontrarem formas mais eficientes para realizarem o seu trabalho.

Nos tópicos seguintes será apresentada a proposta de um modelo de compartilhamento de conhecimento no ambiente de trabalho que, a exemplo de modelos de autores como Szulanski (2000) e Strocchia (2001), supõe que o compartilhamento de conhecimento ocorra em processo integrado por um conjunto de fases. Nesta proposta essas fases são quatro: iniciação, implementação, apoio e incorporação. $\mathrm{O}$ modelo proposto considera, ainda, o suporte de 4 elementos, semelhantes aos que sustentam o processo de comunicação entre pessoas: a fonte do conhecimento a ser compartilhado, o destinatário desse conhecimento, o conhecimento em si, e o contexto em que o compartilhamento de conhecimento ocorre.

\section{Proposta de Modelo de Compartilhamento de Conhecimento No Trabalho}

A proposta de um modelo de processo de compartilhamento de conhecimento no trabalho tem como finalidade ajudar a compreender o que ocorre quando pessoas compartilham no trabalho conhecimentos que possuem, e discutir elementos que integram esse processo, procurando contribuir para melhorar a sua eficiência e resultados. Pretende-se suprir uma lacuna percebida na literatura, que registra poucas iniciativas semelhantes. Entre estas iniciativas estão as propostas de Szulanski (2000) e de Strocchia (2001), que tratam o tema de forma mais ampla, considerando o processo de transferência de conhecimento na organização. No caso do modelo proposto, o foco principal é o processo que ocorre nos grupos de trabalho, sendo a organização considerada como elemento do contexto em que esses grupos estão inseridos. Está ancorado na Teoria de Sistemas (Bertalanffy, 1975) e em teorias da comunicação humana (Berlo, 1970; Thayer, 1979; Thompson, 1973). Tem como pressupostos as cinco explicitações que seguem.

- As organizações funcionam como qualquer sistema vivo, apresentando dois processos básicos: (a) importação de recursos e matérias-primas do meio 
ambiente, que são convertidos em produtos ou serviços, e que por sua vez são exportados para consumo interno ou externo; (b) aquisição de informações, obtidas nos ambientes interno e externo, para serem usadas na solução dos problemas enfrentados e no processo de tomada de decisão, visando ao cumprimento dos objetivos organizacionais.

- As necessidades e funções comunicacionais da organização são atendidas por meio de três sistemas: (a) o de comunicação operacional, que se refere às operações e tarefas que devem ser desempenhadas na organização; (b) o sistema regulador da comunicação, que envolve as ordens, regras e instruções reguladoras dos processamentos que ocorrem na organização; (c) o sistema de feedback relacionado "às condições das pessoas ou dos canais de comunicação dos quais a organização depende para o influxo de recursos ou de informação do meio ambiente" (Thayer, 1979, p. 123).

- A comunicação de que a organização necessita pode ser obstruída por barreiras interpessoais, como a decorrente de atitudes conflituosas ou antagônicas, e barreiras individuais, como hábitos e ações inapropriados, ou inaptidões para receber e compartilhar informações (Thayer, 1979).

- A comunicação possui quatro componentes básicos: fonte, receptor, mensagem e veículo; não é um processo linear, mas circular; tem origem na fonte, passa pelo receptor e retorna alterada à fonte (Thompson, 1973).

- As atitudes da fonte para consigo, com o recebedor, com a mensagem, e para com o sistema cultural-social em que a comunicação ocorre, afetam o processo de comunicação e o seu resultado; o mesmo ocorre em relação às atitudes do receptor para com esses elementos e para com a fonte (Berlo, 1970).

O modelo concebido considera que o processo de compartilhamento de conhecimento é integrado por 4 fases, caracterizadas por ações específicas, próprias de cada fase: iniciação, caracterizada por ações voltadas para identificar e analisar as necessidades de conhecimentos, e as oportunidades existentes para empregar conhecimentos diferentes ou novos, e para localizar fontes onde esses conhecimentos poderão ser encontrados; implementação, com ações voltadas para promover a integração entre fontes e destinatários do conhecimento; apoio, caracterizada por ações voltadas para criar oportunidades de exercitamento do conhecimento compartilhado e para promover orientação da prática, até que ocorra a assimilação do conhecimento e o desenvolvimento das habilidades necessárias ao uso proficiente; e incorporação, fase caracterizada por ações voltadas para fazer com que o conhecimento compartilhado possa fluir livremente entre aqueles que deverão usá-lo. 
A Figura 1 mostra as 4 fases do modelo de compartilhamento de conhecimento no trabalho, associadas às principais ações que caracterizam cada fase, conforme a concepção do modelo aqui proposto.

\section{Figura 1: Modelo de Compartilhamento de Conhecimento}

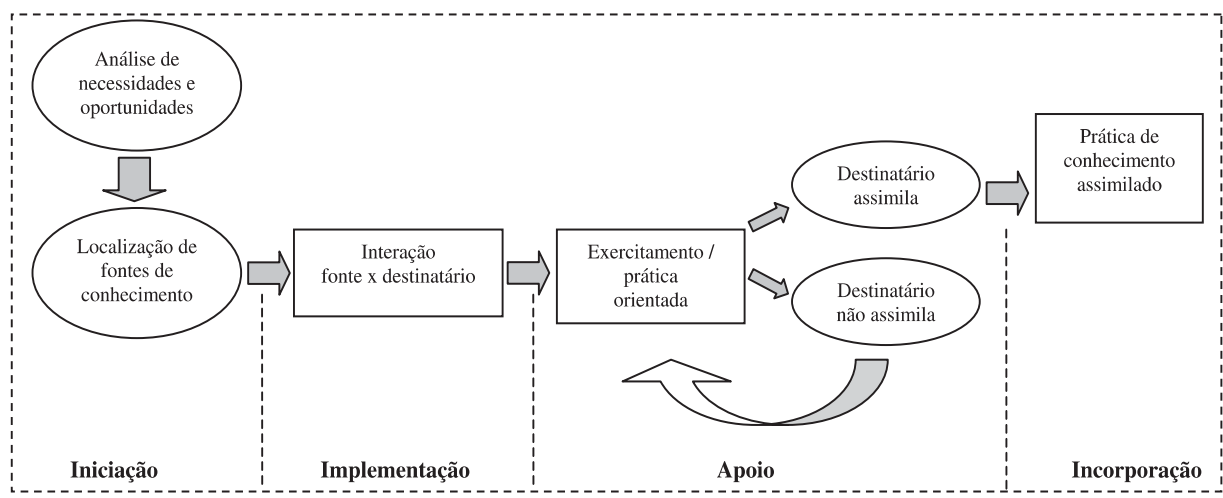

O item a seguir descreve as fases do processo de compartilhamento de conhecimento, previstas no modelo proposto.

\section{Fases do Processo de Compartilhamento de Conhecimento}

O modelo de processo de compartilhamento de conhecimento, considera 4 fases: iniciação, implementação, apoio e incorporação.

\section{a) Fase de Iniciação}

Na primeira fase do processo de compartilhamento de conhecimento, segundo o modelo em tela, é considerada, de um lado, a identificação de necessidades ou demandas de conhecimento, que servirão como estímulo para a localização de fontes de conhecimentos para suprir as carências da pessoa; ou seja, a descoberta de necessidades ou demandas poderá provocar uma busca deliberada de conhecimentos para atendê-las. O ingresso de um novo membro no grupo de trabalho, por exemplo, sugere de pronto, a necessidade de repasse de conhecimento; é prudente, entretanto, que seja feita uma análise de quais conhecimentos deverão ser repassados ao novo elemento, e localizadas as fontes que melhor poderão atender a essa demanda; pode ocorrer que o novato já domine pelo menos parte do conjunto de conhecimentos que deverá possuir, para compreender bem o que ocorre na unidade; e repassar-lhe aquilo que já domina, além de tedioso, seria perda de tempo. Além disso, uma identificação criteriosa 
de necessidades evitará investimentos e esforços desnecessários na aquisição de conhecimentos que poderão não ser úteis para o indivíduo, o seu grupo de trabalho e para a organização.

A primeira fase do modelo considera, também, a possibilidade de serem encontrados conhecimentos disponíveis, já existentes na unidade de trabalho do indivíduo, ou na organização, que não estão sendo usados, ou que poderiam ser mais bem e mais amplamente aplicados; a localização desses conhecimentos, e a indução do seu compartilhamento poderá contribuir para solucionar problemas ou atender demandas existentes, e até mesmo transformar-se em vantagem competitiva para a organização. É sabido que existem na organização conhecimentos que permanecem ocultos e sem aplicação, que as pessoas geralmente sabem muito mais do que costumam mostrar no dia-a-dia, e que muitos conhecimentos que permanecem restritos a alguns indivíduos ou a determinadas áreas, poderiam ser usados por outros, ou em outras unidades de trabalho, com vantagens para a organização.

A relevância da etapa de iniciação depende do grau de dificuldade existente para, (a) localizar demandas existentes; (b) perceber oportunidades de transferir a outros conhecimentos úteis já dominados, mas ainda circunscritos a pessoas ou unidades de trabalho (Szulanski, 2000); e (c) manter contextos propícios à busca e à criação de conhecimento. A relevância aumenta, quando existem situações desfavoráveis para a organização, como a perda de mercados, prejuízos, erros repetidos, desempenhos insuficientes, ou a necessidade de inovar para fazer frente a competidores agressivos (Clarke \& Monkhouse, 1995), situações que poderão ser revertidas com a introdução de conhecimentos especializados ou novos.

As principais dificuldades encontradas nessa fase do processo de compartilhamento de conhecimento referem-se à: identificação precisa das necessidades ou demandas de conhecimento; localização de fontes aptas e disponíveis para repassarem conhecimento; gestão de competências de fontes e destinatários necessárias para viabilizar o compartilhamento do conhecimento; gestão de aspectos do contexto organizacional, incluindo crenças e atitudes existentes na cultura interna que possam impactar o processo.

A existência de uma cultura organizacional aberta ao diálogo e à discussão de problemas e idéias, pode favorecer a descoberta de soluções para demandas organizacionais (Davenport \& Prusak, 1998; Nonaka \& Takeuchi, 1997), e facilitar a localização de fontes de conhecimento; uma prática simulada de gestão de situações de demanda ou crise, como a prática da flutuação ou caos criativo do modelo de criação do conhecimento de Nonaka e Takeuchi (1997) também poderá ser um recurso para estimular a busca de conhecimento. Da mesma forma, a descoberta casual e não planejada de conhecimento útil que poderá ser 
compartilhado, mesmo quando decorrente do acaso, terá maior probabilidade de ocorrer se existir na organização o interesse por essa prática, se existirem crenças e atitudes convergentes com ela, ou seja, um contexto propício.

\section{b) Fase de Implementação}

Nessa fase são estabelecidos vínculos entre a fonte possuidora do conhecimento e o demandante ou destinatário do conhecimento a ser compartilhado; os focos de maior interesse nessa fase são as trocas que ocorrem entre a fonte e o destinatário, e as condições em que elas ocorrem. Os problemas que poderão ocorrer nessa fase estão relacionados mais diretamente (a) com as habilidades da fonte para repassar aquilo que sabe, e do destinatário, para compreender e conseguir manejar o conhecimento que está sendo compartilhado; (b) com as atitudes e traços pessoais de ambos, que poderão facilitar ou dificultar o processo, a depender de como se coloquem diante do compartilhamento de conhecimento; e (c) com aspectos do contexto organizacional, como disponibilidade de tempo e condições estruturais adequadas para o compartilhamento; como, por exemplo, situações formais e informais para encontros e conversas entre as pessoas, e locais e equipamentos adequados para o repasse de conhecimentos que exigem demonstrações.

O planejamento cuidadoso das ações necessárias ao compartilhamento de conhecimento poderá contribuir para evitar problemas que possam reduzir ou impedir os seus resultados desejados. Entre as ações passíveis de planejamento estão: (a) a identificação do conhecimento a ser compartilhado, seu volume e fracionamento em unidades a serem repassadas; (b) a escolha de estratégias que serão empregadas, por exemplo, verbalização, simulações, práticas; (c) o controle de variáveis relacionadas à fonte e ao receptor, tais como: sobrecarga de atividades; preparo para repassar o conhecimento de forma efetiva; domínio de competências consideradas requisitos para a apreensão do conhecimento; crença na viabilidade e oportunidade do compartilhamento; (d) o cuidado com a recorrência de problemas já conhecidos, que poderão afetar a disposição e o interesse tanto da fonte quanto do destinatário do conhecimento; (e) a existência de critérios de avaliação do progresso obtido no compartilhamento.

A implementação do conhecimento é auxiliada com o uso da redundância (Nonaka \& Takeuchi, 1997), que é um recurso para assegurar a qualidade da recepção do conhecimento compartilhado. "Na teoria da informação, a redundância mede o excedente relativo de signos com relação ao número mínimo que teria sido necessário para carregar a mesma quantidade de informação" (Amado \& Guittet, 1978, p. 18). Ou seja, considerado o mesmo número de signos, a informação mais redundante conterá menor quantidade de informação. Na conversação humana 
os gestos podem intensificar o sentido da informação repassada no discurso, caracterizando uma forma de redundância; a repetição de uma mesma frase, dita com palavras diferentes, é outra forma de redundância.

A redundância será tão mais necessária e útil quanto maior for o desconhecimento do receptor em relação ao conhecimento que deverá assimilar; seu uso confere ao emissor maior segurança quanto à efetividade do repasse de conhecimento que realiza. Ao usar esse recurso a fonte do conhecimento deverá transmitir parcelas limitadas de informação, e repeti-las até várias vezes se necessário, em vez de transmitir maior quantidade de informações, de uma só vez; poderá repetir palavraschaves, ou ações-chaves, e pedir que o destinatário as empregue até verificar que ocorreu a assimilação desejada. $\mathrm{O}$ uso de redundância reduz o volume de informação repassado em certo período de tempo, mas aumenta a probabilidade de o destinatário assimilar a parcela de conhecimento compartilhado.

A troca de conhecimentos estabelecida entre a fonte e o destinatário poderá ser sincrônica ou diacrônica. A diferença entre essas duas formas de intercomunicação "é semelhante à que existe entre monólogo e diálogo" (Thayer, 1979, p. 148). Uma fonte pode simplesmente transmitir um conhecimento que detém sobre como resolver dado problema, a um receptor que escuta e descodifica o que ouve com base nos referenciais linguísticos, tecnológicos e vivenciais que possui. Nesse caso, estará ocorrendo uma intercomunicação sincrônica (monólogo). Essa comunicação se tornará diacrônica, se fonte e receptor passarem a analisar o problema e a estudar soluções alternativas que poderão ser encontradas para a sua solução (diálogo); ou seja, ocorre comunicação diacrônica se, tanto a expertise da fonte, quanto as dúvidas e experiências pessoais do destinatário, forem colocadas numa arena comum, visando à busca do conhecimento que irá solucionar o problema em discussão. São exemplos dessa arena, as comunidades de práticas e a ba, que na língua japonesa significa lugar, e que é citada por Nonaka e Konno (1998) como lugar ideal para a criação e transferência de conhecimento.

$\mathrm{Na}$ forma sincrônica, existe a expectativa de ocorrer a sincronização entre os atores envolvidos no compartilhamento do conhecimento, ou seja, o conhecimento da fonte é assimilado pelo destinatário na forma como lhe é passado, e ambos, fonte e destinatário, passam a deter o mesmo conhecimento, ainda que em graus diferentes de experiência em sua aplicação. Na forma sincrônica ocorre um estado em que, após a intercomunicação, o conhecimento alvo do processo foi repassado da fonte para o destinatário.

Na forma diacrônica, o resultado esperado é que ocorra um novo estado de coisas entre a fonte e o destinatário, ou entre eles "e seus respectivos meios ambientes" (Thayer, 1979, p. 149). A forma diacrônica prevê que do esforço 
conjugado e cooperativo de comunicação entre fonte e destinatário, decorra como resultado um estado de conhecimento diferente e possivelmente maior e mais significativo do que o existente anteriormente ao encontro de ambos. Ou seja, tanto o destinatário como a fonte, saem do processo de compartilhamento com conhecimento diferente e possivelmente maior do que no início do processo.

A relevância da implementação está relacionada: com o grau de necessidade de o destinatário aplicar em suas atividades o conhecimento alvo do processo de compartilhamento; com o valor que essa aplicação poderá gerar para a organização; com a insuficiência de portadores ou fontes do conhecimento a ser compartilhado, que será tão mais relevante quanto menor for o número e disponibilidade de fontes; com o rompimento das rotinas da fonte e do destinatário (Szulanski, 2000), para dedicar tempo e atenção ao compartilhamento.

As principais dificuldades encontradas na fase de implementação de um processo de compartilhamento de conhecimento, poderão estar relacionadas à: (a) dificuldades de comunicação e uso de linguagem e códigos comuns, pela fonte e pelo destinatário do conhecimento; (b) resistência da fonte em repassar o conhecimento que detém, por receio de perder status ou poder, por temer ser substituído pelo aprendente, ou outros motivos; (c) resistência do destinatário em adquirir o conhecimento, devido a não estar disposto a mudar a forma como trabalha, por sentir desconforto em colocar-se na posição de aprendente, por temer não assimilar a nova aprendizagem, ou outro; (d) falta de interesse e comprometimento com as demandas da organização, tanto da parte da fonte como do destinatário; (e) existência na organização de gerentes com estilos de gestão refratários à cooperação interna, e conseqüentemente, ao compartilhamento de conhecimento; (f) necessidades de mudança de hábitos e práticas pessoais de pensamento e de trabalho do destinatário, e às vezes de seus pares, geralmente internalizadas de forma profunda e com pouca chance de mudança; (g) possíveis necessidades de revisão de crenças, atitudes e valores arraigados na cultura organizacional, que em decorrência do compartilhamento do conhecimento precisarão ser abandonados ou substituídos.

A análise particularizada dessas dificuldades mostra que as soluções possíveis exigem empenho para: aperfeiçoar os processos de comunicação interpessoal, intergrupal e organizacional; reduzir as inseguranças que as pessoas possam ter em relação à organização; criar clima propício ao envolvimento voluntário, à cooperação e ao estabelecimento da confiança entre as pessoas; estimular a aquisição de novas competências, a prática da reflexão, a mudança de modelos mentais, e a aprendizagem contínua; buscar a adoção de estilos gerenciais facilitadores do trabalho cooperativo e do comprometimento das pessoas com o que fazem; e adotar políticas que incentivem e valorizem o compartilhamento de conhecimento. 


\section{c) Fase de Apoio}

A fase de apoio do modelo de compartilhamento de conhecimento supõe a necessidade e a existência de oportunidades para esclarecer e retificar conhecimentos repassados que ainda mereçam atenção, para evitar que passem a ser usados de forma ineficiente ou inadequada. A relevância da fase está relacionada ao volume e gravidade dos problemas surgidos nas primeiras tentativas de aplicação do conhecimento compartilhado, e do esforço exigido para encontrar e encaminhar as necessárias soluções.

Entre os problemas que podem surgir na fase de apoio estão: (a) reações do ambiente à prática do conhecimento compartilhado e suas consequências; por exemplo, o compartilhamento de nova metodologia de trabalho poderá levar a mudanças no desempenho de funções ou cargos, com possível aumento ou redução de responsabilidades e de níveis de poder em algumas posições, gerando resistências dos atingidos; (b) falta de linguagem comum entre os usuários ou aplicadores do conhecimento compartilhado; (c) treinamento insuficiente dos usuários para a aplicação do conhecimento; (d) dificuldades de assimilação por falta de requisitos pessoais necessários ao uso do conhecimento compartilhado; (e) retomada de conhecimentos dominados anteriormente, por parecerem mais fáceis e rápidos de aplicar nas situações de sobrecarga de trabalho; (f) falta de acesso à fonte do conhecimento, para solução de dúvidas surgidas; (g) desempenho insuficiente ou fora dos padrões esperados; (h) falta de condições físicas e materiais necessários para a prática do novo conhecimento; (i) movimentação de pessoas pós-compartilhamento de conhecimento para posições impeditivas da sua aplicação; desligamento de pessoas envolvidas no compartilhamento de conhecimento, e a conseqüente perda desse conhecimento; (j) mudanças tempestivas, que forçam redirecionamentos da organização e afetam a forma como os indivíduos realizam o trabalho.

Problemas surgidos nessa fase devem ser enfrentados o mais rápido possível, devido ao agravamento a que podem ser levados; práticas incorretas, quando se tornam arraigadas, são mais difíceis de serem removidas. Nessa fase, a aplicação do conhecimento compartilhado poderá ocorrer de forma gradual ou imediata. No primeiro caso, em uma mesma situação, a prática do conhecimento compartilhado tenderá a coexistir com outras similares, dominadas anteriormente pelos recebedores do conhecimento, até que ocorra a total substituição destas. No segundo caso, a substituição das práticas será imediata à adoção do conhecimento.

\section{d) Fase de Incorporação}

$\mathrm{O}$ conhecimento compartilhado tende a ser incorporado à medida que o 
recebedor ou destinatário aplica o conhecimento no seu dia-a-dia, e principalmente quando mais pessoas começam a fazer o mesmo. A relevância da fase de incorporação está relacionada ao esforço para remover obstáculos ao uso do conhecimento compartilhado, e para lidar com os desafios surgidos para a sua aplicação, o que pode depender de mudanças no trabalho realizado pelo recebedor, ou na unidade de trabalho à qual está vinculado, e até mesmo na própria organização.

Essa fase poderá ser conturbada por eventos externos, como mudanças ambientais, e também por eventos internos, tais como: (a) expectativas inadequadas dos recebedores, por estarem aplicando o novo conhecimento; exemplo, expectativas não previstas de promoção ou atribuição de diferencial salarial, devido à agregação de novas competências com o conhecimento assimilado; (b) exigência de aplicação do conhecimento em situações não totalmente esclarecidas; exemplo: orientação para transpor conhecimento de uma situação para outra, sem que as implicações da ação estejam plenamente claras; (c) evidências de conseqüências disfuncionais ou indesejáveis, decorrentes do uso do conhecimento; exemplo, redução de quadro funcional e desligamento de pessoal; (d) mudanças súbitas nas atividades realizadas pelas pessoas, que dificultem ou inviabilizem o uso do novo conhecimento; exemplo, atribuição de novas e diferentes atividades, com sobrecarga de trabalho para os indivíduos.

As principais dificuldades existentes nessa fase estão relacionadas com a capacidade de gestão dos conflitos organizacionais quanto ao uso do conhecimento, indicadas anteriormente, e com as habilidades e atitudes necessárias para a aplicação do conhecimento. As pessoas podem divergir nas rotinas de aplicação do conhecimento compartilhado, devido a: (a) diferenças nos mecanismos de percepção dos benefícios e das ameaças que poderão advir do seu uso rotineiro; (b) falta de habilidades para redirecionar ações e rever as rotinas, quando ocorrem obstáculos ou dificultadores ao emprego do conhecimento de forma rotinizada; (c) resistência ou indisponibilidade das pessoas para mudanças que se tornam necessárias, à medida que as práticas decorrentes do novo conhecimento começam a se consolidar; (d) descrédito, e conseqüente pressão contrária, das chefias e pares sobre as vantagens e benefícios do uso do novo conhecimento.

O modelo de compartilhamento de conhecimento, anteriormente descrito, supõe a existência de um processo que evidencia 4 elementos básicos, análogos aos do processo de comunicação (Thayer, 1979; Thompson, 1973): a fonte do conhecimento, o destinatário, o conhecimento a ser compartilhado, e o contexto em que o compartilhamento de conhecimento ocorre. Esses elementos são descritos no item a seguir. 


\section{Elementos do Processo de Compartilhamento de Conhecimento}

O modelo proposto considera como elementos básicos do processo de compartilhamento do conhecimento, a fonte do conhecimento, o seu destinatário, o conhecimento em si, que é alvo da ação de compartilhar, e o contexto em que o compartilhamento ocorre.

\section{a) A Fonte do Conhecimento}

É quem possui o conhecimento a ser compartilhado e pode ser descrita, principalmente, por meio (a) de suas habilidades de comunicação, (b) suas atitudes frente a si mesma, ao destinatário, ao conhecimento a ser compartilhado, e ao contexto organizacional, (c) o nível de domínio que possui do conhecimento que pretende repassar, (d) e a posição que ocupa no contexto organizacional em que está inserida (Berlo, 1970).

Uma fonte será mais efetiva ao compartilhar conhecimento na medida em que tiver maior domínio das habilidades inerentes ao processo de comunicação; como, por exemplo, o domínio de vocabulário adequado para exprimir conhecimento explícito, e de metáforas e imagens para transmitir conhecimento tácito. $\mathrm{O}$ fato de julgar-se competente e valorizada pelo conhecimento que possui pode ajudar a fonte a ser mais efetiva, ao compartilhar conhecimento, da mesma forma que o julgamento inverso poderá dificultar o compartilhamento.

Crer naquilo que está fazendo, na mensagem que está repassando, pode contribuir para maior efetividade da fonte. Uma atitude favorável ao destinatário - por exemplo, acreditar que ele é capaz de apreender o conhecimento que está sendo compartilhado - também tende a aumentar a efetividade do compartilhamento de conhecimento. Ou então, ver o contexto organizacional como sendo propício e o ato de compartilhar conhecimento como benéfico e vantajoso, também tenderá a ajudar a fonte a ser mais efetiva (Davenport \& Prusak, 1998). A motivação da fonte para compartilhar conhecimento é influenciada pelo esforço exigido nesse processo, e pelo incentivo que recebe, que poderá ser para cooperar com o destinatário, ou competir com ele. Neste caso o compartilhamento tende a ser prejudicado (Szulanski, 2000).

O nível de domínio do conhecimento a ser compartilhado é outro aspecto que interfere no processo em estudo; ninguém é capaz de repassar algo que não possui; por outro lado, se a fonte é por demais especializada, poderá ter dificuldade de entrar em sintonia com um destinatário neófito em sua área, e errar ao empregar linguagem e procedimentos técnicos que o recebedor não consiga entender. 
Também o contexto organizacional e a forma como a fonte nele está inserida podem influenciar o repasse de conhecimento: o tipo de organização e a realidade organizacional, as crenças e valores que permeiam essa realidade, os papéis que a fonte desempenha na organização, suas atribuições, o prestígio que possui, a influência que consegue exercer, são aspectos que interferem no desempenho da fonte ao repassar o que sabe. Grupos ou equipes de trabalho habituados a ouvir os seus próprios membros, acostumados a procurar intragrupo o conhecimento de que precisam antes de buscá-lo fora, contribuem para que as pessoas se disponham a assumir o papel de fonte repassadora de conhecimento no trabalho.

\section{b) O Destinatário do Conhecimento}

É quem apresenta a expectativa ou a necessidade de adquirir o conhecimento; a necessidade pode não estar clara para o destinatário, e a aquisição do conhecimento pode representar um desafio significativo para ele, em particular se exigir o abandono de práticas já dominadas, que deverão ser substituídas por novas práticas. É identificado também como recebedor ou receptor do conhecimento.

Da mesma forma que a fonte, também o destinatário poderá ser descrito por meio de habilidades comunicadoras, atitudes frente a si, ao conhecimento que recebe, à fonte que o transmite, e ao contexto em que está posicionado e a forma como isso ocorre. Se possui habilidades para ouvir e refletir sobre o que the passam, ou para elaborar perguntas que permitam esclarecer informações recebidas e direcionar a sua aplicabilidade; se acredita ser capaz de aprender e usar bem o novo conhecimento; se vê o conhecimento a ser apreendido como importante para si e para o seu trabalho; se percebe a fonte do conhecimento como capaz e confiável; e se partilha os valores e crenças do contexto organizacional ao qual pertence, certamente terá maior facilidade em incorporar o novo conhecimento. O status social, os componentes do grupo, conhecimentos anteriores, hábitos e costumes já internalizados, "afetam os modos pelos quais recebe e interpreta as mensagens" (Berlo, 1970, p. 53).

\section{c) O Conhecimento a ser Compartilhado}

O conhecimento a ser compartilhado corresponde, no processo de comunicação, à mensagem, e como ela deve possuir três características básicas: compreensibilidade, validade, utilidade (Thayer, 1979). Validade e utilidade estão relacionadas à aplicação do conhecimento, ao quanto e ao como o conhecimento compartilhado poderá atender às demandas ou necessidades que deram origem ao compartilhamento. A compreensibilidade está relacionada tanto ao 
conhecimento que é compartilhado, quanto ao processo usado para o seu compartilhamento. Maior compreensibilidade resulta em menor ambigüidade no resultado ou produto do compartilhamento. "Na medida em que o receptor não pode, pronta e eficientemente, retirar a ambigüidade da mensagem do originador - no sentido de bem interpretar o que o originador quis dizer com suas palavras a mensagem permanecerá (...) incompreensível para o receptor" (Thayer, 1979, p. 185). Alto nível de ambigüidade pode corresponder a baixo nível de transferência do conhecimento, mesmo que haja grande empenho no seu compartilhamento.

\section{d) O Contexto em que o Conhecimento é Compartilhado}

O contexto em que o compartilhamento de conhecimento ocorre influencia fortemente esse processo. Estruturas muito centralizadas e formais podem inibir a criação e a disseminação de conhecimentos. Normas e procedimentos detalhados, a exigência de que as coisas sejam feitas de forma sempre igual, a imposição de sanções rígidas aos erros cometidos, sem que haja distinção entre erros de aprendizagem e erros de descaso, são exemplos de situações que inibem o compartilhamento de conhecimento. Experiências bem sucedidas de gestão do conhecimento evidenciam que a prática do compartilhamento de conhecimento, embora vinculada às características da organização, independe do tipo de organização em que é praticado (Cong \& Pandya, 2003). É certo, entretanto, que as organizações autocráticas, com procedimentos rígidos, tendem a inibir o compartilhamento de conhecimento, sejam elas empresas públicas ou privadas, órgãos de governo ou organizações não governamentais. Algumas variáveis de contexto se mostram particularmente relacionadas ao compartilhamento de conhecimento, como as atitudes e crenças predominantes na cultura e a liderança, ou o apoio formal dado ao compartilhamento. Em uma mesma organização, subculturas refratárias ao compartilhamento de conhecimento podem coexistir com outras, mais favoráveis.

Entre as muitas estratégias que poderão gerar um contexto propício ao compartilhamento de conhecimento, está a construção de relacionamentos cooperativos e de confiança mútua; a confiança surge da coerência entre os valores que são postulados e a sua vivência no cotidiano da organização, surge da coerência entre discurso e prática; as organizações que fomentam a confiança costumam ouvir e valorizar as idéias e praticar o tratamento igualitário e justo; está também o estabelecimento de um clima misto de consenso e questionamento contínuo, construído por meio de treinamentos, discussões, leituras, trabalhos em equipe e rodízio de funções e papéis; estão ainda a disponibilização de espaços e tempo para o compartilhamento de conhecimento; a realização de reuniões frequentes e rápidas; o abandono do olhar acostumado; o estímulo ao questionamento e o apoio ao fazer diferente; a incorporação na linguagem cotidiana, 
de aforismos ou máximas estimuladores de mudança, tais como: “... e por que não?...", ou então, “...se funcionou, está na hora de melhorar...", ou ainda, “...manda quem pode, faz diferente quem sabe...".

\section{ConClusões}

O conhecimento é um recurso estratégico importante para as organizações, tanto públicas quanto privadas, e cada vez mais elas se dão conta de que precisam descobrir o que sabem, e usar esse saber. A gestão do conhecimento é um processo que busca otimizar o uso desse recurso, e que tem, como um de seus alvos, o compartilhamento de conhecimento, que é o foco do presente artigo.

A proposta de um modelo de compartilhamento de conhecimento, aqui apresentada, visa auxiliar a reflexão sobre esse processo, considerado vital no atual contexto das organizações. O compartilhamento de conhecimento no trabalho tende a ser difícil, e está sujeito à interferência de inúmeras variáveis, que quanto mais forem conhecidas, mais bem gerenciadas poderão ser. A importância do modelo reside no fato de localizar diferentes fases do processo de compartilhamento de conhecimento, e relacionar a cada fase, situações pessoais e organizacionais que poderão ocorrer e interferir no processo; além disso, também oferece orientações para ajudar a refletir sobre os elementos que integram o processo de compartilhamento, ou seja, a fonte, o destinatário, o próprio conhecimento e o contexto em que este pode ser compartilhado.

Ao longo da vida as pessoas criam e desenvolvem conhecimento tácito, na família, no trabalho que realizam, em atividades voluntárias, quando praticam esportes, quando estudam, quando assumem papéis sociais. As soluções que encontram para resolver os problemas que vivenciam ficam arquivadas na mente humana, e muitas podem ser transpostas de uma situação para outra, às vezes com apenas pequenos ajustes.

O mesmo ocorre com a organização: todas as soluções encontradas para os pequenos e grandes problemas que enfrenta, ao longo de sua existência, podem representar um acervo valioso, que lhe permitirá potenciar cada vez mais sobre o conhecimento já dominado, inovar com maior segurança, ousar e correr riscos calculados, e ganhar tempo, um recurso que normalmente é escasso. Entretanto esse conhecimento é de difícil registro, e a probabilidade maior é que permaneça apenas na cabeça de quem esteve envolvido diretamente nas questões que lhe deram origem; ou seja, os demais colegas que trabalham na organização desconhecem o conhecimento existente, gerado com a solução das questões; e, 
quando qualquer um destes se depara com um problema semelhante, ou até o próprio problema resolvido anteriormente, tem que refazer todo o caminho já percorrido.

O conhecimento explícito, por sua vez, embora sendo mais fácil de ser repassado entre pessoas e unidades de trabalho, também merece atenção, principalmente no que diz respeito a sua codificação e registro, de forma a poder ser rapidamente recuperado sempre que solicitado. De que adianta saber que a organização possui determinada informação, e que essa informação está em certo documento, mas que este está perdido em uma selva de pastas em um arquivo físico ou eletrônico? $\mathrm{Na}$ hora em que for encontrado, provavelmente, não mais atenderá à situação que provocou a sua busca, e a organização poderá ter perdido uma oportunidade de negócio. Ou, então, para que servem os relatórios sobre desempenho e resultados, se eles ficam circunscritos à diretoria, e não chegam às pessoas que executam o trabalho e produzem os resultados?

Essas são razões pelas quais as organizações devem ocupar-se com o compartilhamento de conhecimento, seja ele explícito ou tácito; porque devem investir na criação de ambientes favoráveis à livre circulação do conhecimento; ambientes propícios a que os indivíduos se encontrem e conversem com frequiência, se habituem a falar e a ouvir, a agir como fonte e como receptores de conhecimento. São razões que justificam investimentos na criação de oportunidades, para que as pessoas relatem, umas para as outras, as soluções que encontram para os problemas que enfrentam no trabalho cotidiano. É óbvio, que anterior a essa prática, deve existir outra, sem a qual pouco adiantará as pessoas conversarem entre si; elas precisam ter autonomia para executarem o seu trabalho, para buscarem, elas próprias, os melhores caminhos para os problemas que encontram; se forem obrigadas a estar sempre recorrendo às respectivas chefias, para ouvirem destas o que devem e o que podem fazer, não conseguirão agregar ao trabalho o valor da experiência que possuem.

É bom lembrar que estamos falando de um contexto em que o conhecimento diferente e inovador pode agregar valor ao trabalho realizado pelo indivíduo; sendo assim, potencialmente todo indivíduo poderá melhorar o processo e os resultados do seu trabalho na medida em que possa incorporar ao que faz as aprendizagens obtidas nas mais diversas situações de sua vida pessoal. Posições funcionais e tarefas estritamente rotineiras, e que assim devem permanecer, não comportam o tipo de reflexão que aqui está sendo feita.

Outra questão que é colocada para as organizações que dependem de conhecimento, é a necessidade do estabelecimento de estruturas flexíveis e mais horizontais, permeáveis às iniciativas e sugestões das pessoas, independentemente da posição que ocupem na 
hierarquia da organização. Quem realiza o trabalho na linha de frente pode, sim, ter um conhecimento mais preciso sobre o que está ocorrendo na sua área, do que, por exemplo, o diretor que planejou esse trabalho, por mais competente que seja este. E o compartilhamento desse conhecimento da ponta executora pode ser decisivo para a definição da estratégia de mercado da organização.

A apresentação do modelo de compartilhamento de conhecimento proposto neste artigo indica várias situações do contexto organizacional que podem interferir nos fluxos de conhecimento entre fontes e receptores, estejam estes na base, nos níveis intermediários, ou no topo da hierarquia da organização. Uma adequada gestão dessas situações poderá estimular o compartilhamento de conhecimento entre pessoas no trabalho e, em conseqüência, melhorar os resultados da organização. Essa é a finalidade do modelo proposto.

\section{Artigo recebido em 27.04.2004. Aprovado em 10.08.2004.}

\section{Referencias Bibliográficas}

Amado, G., \&

Guittet, A. (1978).

A dinâmica da comunicação nos grupos (A. T. Ribeiro, Trad.). Rio de Janeiro: Zahar Editores. (Obra original publicada em 1975).

Bartol, K., \&

Srivastava, A. (2002, Summer).

Encouraging knowledge sharing: the role of organizational reward systems. Journal of Leadership \& Organizational Studies, 9(1), 64-76

Berlo, D. K. (1970).

O processo da comunicação: introdução à teoria e prática (J. A. Fortes, Trad.). Rio de Janeiro: Editora Fundo de Cultura S.A. (Obra original publicada em 1960).

Bertalanffy, L. V. (1975).

Teoria geral de sistemas (2a ed.). Petropólis: Vozes. (Obra original publicada em 1968).
Clarke, T., \&

Monkhouse, E. (1995).

Repensando a empresa (N. Montingelli, Trad.). São Paulo: Pioneira. (Obra original publicada em 1994).

Cong, X., \&

Pandya, K. V. (2003, December).

Issues of knowledge management in the Public sector. Electronic Journal of Knowledge Management, 1(2). Recuperado em 15 fevereiro, 2004, de http://www.ejkm.com

Davenport, T. H., \&

Prusak, L. (1998).

Conhecimento empresarial: como as organizações gerenciam o seu capital intelectual (L. Peres, Trad.). Rio de Janeiro: Campus. (Obra original publicada em 1998). 
Goman, C. K. (2002).

Five reasons people don't tell what they know. Kinsey Consulting Services. Recuperado em 11 setembro, 2003, de http://www.ckg.com/ archive19.htm

Krogh, G. V.,

Ichijo, K., \&

Nonaka, I. (2001).

Facilitando a criação de conhecimento - reinventando a empresa com o poder da inovação contínua (A .C. C. Serra, Trad.). Rio de Janeiro: Campus. (Obra original publicada em 2000).

Maturana, H. R., \&

Varela, F. J. (2001).

A árvore do conhecimento: as bases biológicas da compreensão humana (H. Mariotti, \& L. Diskin, Trad.). São Paulo: Palas Athena. (Obra original publicada em 1984).

Nonaka, I., \&

Konno, N. (1998, Spring).

The concept of "ba": building a foundation for knowledge creation. California Management Review, 40(3), 40-54.

Nonaka, I., \&

Takeuchi, H. (1997).

Criação do conhecimento na empresa (A. B. Rodrigues, Trad.). Rio de Janeiro: Campus. (Obra original publicada em 1995).
Strocchia, M. (2001).

MCTC: Metodologia para la captura $y$ transferencia de conocimiento. Fundación Iberoamericana del conocimiento. Recuperado em 11 janeiro, 2003, de http:// www.gestiondelconocimiento.com

Sveiby, K. E. (1998).

A nova riqueza das organizações (L. E. T. Frazão, Trad.). Rio de Janeiro: Campus. (Obra original publicada em 1997).

Szulanski, G. (2000, May).

The process of knowledge transfer: a diachronic analysis of Stickness. Organizational Behavior and Human Decision Processes, 82(1), 9-27.

Terra, J. C. C. (2000).

Gestão do conhecimento. São Paulo: Negócio Editora.

Thayer, L. O. (1979).

Comunicação fundamentos $e$ sistemas: na organização, na administração, nas relações interpessoais (E. Nascimento, \& S. Coutinho, Trad.). São Paulo: Atlas. (Obra original publicada em 1968).

Thompson, J. J. (1973).

Anatomia da comunicação (J. M. Salazar, Trad.). Rio de Janeiro: Bloch Editores S.A. (Obra original publicada em 1969). 